\title{
MARRIAGE CAPACITY, SOCIAL VALUES AND LAW-MAKING PROCESS
}

\section{Kristi Joamets ${ }^{1}$}

\section{Tallinn Law School, Tallinn University of Technology, Estonia email: Kristi.Joamets@siseministeerium.ee}

JOAMETS, Kristi. Marriage Capacity, Social Values and Law-Making Process. International and Comparative Law Review, 2012, Vol. 12., No. 1, pp. 103-121. DOI: 10.1515/iclr-2016-0081.

\begin{abstract}
This article explores capacity to marry in depth, beyond the literal statements presented by legal acts in Estonia. The discussion will be focusing on answering the following questions: What is the nature of marriage capacity and how it has been developed in Estonia? What are the values that the Estonian Family Law Act (2010) protects when regulating marriage capacity? In addition a brief comparative analysis will seek to explain how different regulations of the EU memberstates on the same matter (marriage capacity) are. This can also help discussions on whether is it justified to talk about cultural differences of EU member states in the context of marriage capacity or not.
\end{abstract}

Keywords: family law, marriage, marriage capacity, social values, marriage impediments, law-making process, assessment of social values, private international law

\section{Introduction}

Disharmony in the field of family laws within the European Union (EU) is explicable, taking into account the cultural and historical factors that characterize this branch of laws. However, the European Union policy and the practice of private international law explains a certain degree of flexibility in the application of rules when cases involve citizens from different states. One important area that requires legislative development or doctrinal clarification is marriage capacity, considering that this is a region where freedom of movement is protected, encouraged and facilitated. Especially concerning are changes in domestic legislation affecting the very nature of this traditional institution namely, laws on cohabitation, ostensible marriages, and same sex marital contracts.

1 Kristi Joamets Master of social sciences. Ph.D candidate, lecturer of Tallinn Law School, Tallinn University of Technology. Email: Kristi.Joamets@siseministeerium.ee 
Certifying the contract of marriage involves an administrative deed where administrative body needs to apply both, domestic and supranational legal principles. One of the elements of the essence of a contract is capacity. This imposes an obligation to the administrative body in charge of verifying the substance and meaning of the party's marriage capacity. When the law of other states must also be applied, questions about the values and principles of marriages or marriage capacity, could be raised. Estonian administrative officials do not usually assess the meaning of marriage or marriage capacity. In everyday practice, following the legal procedures merely requires literal interpretation techniques. Other hermeneutical resources such as consulting the spirit of the norm (teleology) or the historic background behind the rules (historical), are rarely even considered. This situation could lead to the adoption of unreasonable, inadequate decisions.

This article explores capacity to marry in depth, beyond the literal statements presented by legal acts in Estonia. The discussion will be focusing on answering the following questions: What is the nature of marriage capacity and how it has been developed in Estonia? What are the values that the Estonian Family Law Act (2010) protects when regulating marriage capacity? In addition a brief comparative analysis will seek to explain how different regulations of the EU memberstates on the same matter (marriage capacity) are. This can also help discussions on whether is it justified to talk about cultural differences of EU member states in the context of marriage capacity or not.

Baltic Private Law (1865) regulating marriage capacity, and similar provisions, or their equivalent in other EU memberstates ${ }^{2}$ are the subjects of this discussion, also the last Estonian Family Law Act (2010), that provides the grounds to study the content of social values during its legislative development process. The legal science methodology is qualitative-analytical, theory will be discussed, contrasted, revised for consistency, compared and commented. Conclusions are drawn based on interpretation of laws, doctrine and practice.

\section{What is marriage capacity?}

Marriage capacity ${ }^{3}$ is an element of validity of the marriage contract. According to A. Lüderitz (2005) this is a special legal capacity different from traditional legal capacity in contract law. ${ }^{4}$

2 Von Freyhold, Vial \& Partner Consultations, (2008) Facilitating Life Events, Final Report for the European Commission, DB-Directorate-General for Justice, Freedom and Security on the project No JLS/2006/C4/004 http://ec.europa.eu/civiljustice/publications/docs/ study_ms_legislation_country_reports_en.pdf. 12.05.2012.

3 For the purposes of this article, the following terms are used interchangeably in literature and legal acts - marriage capacity, marriage ability, assumptions to marry, marriage impediments, marriage obstacles etc.

4 A. Lüderitz.Perekonnaõigus. Õpik. Günther Beitzke alustatud teose 27., ulatuslikult ümbertöötatud trükk, Tallinn, Juura, 2005. p 49. 
Capacity to marry is measured by the personal law. ${ }^{5}$ In overborder marriages the conflict of laws arises related to marriage capacity most and not by the law of the place of celebration, is quite independent of any general theory of capacity to enter into contracts. Marriage is an affair, not of contract, but of status ${ }^{6}$.

Marriage capacity implies that a person has no obstacles to marry other person. The extent of this capacity is defined by gender, age, general legal capacity, kinship, validity of previous marriage(s). The concept of marriage capacity is an evolving one, related to historical, religious, cultural and social values of states or region. Nevertheless, according to the recommendations of the International Commission of Civil Status (ICCS) European Union memberstates cannot establich race, nationality and religion as an impediment to marry ${ }^{7}$.

Common prequisites are gender and civil status - being single. Marriage capacity is based on different aspects in every country: legal, physical and mental. Legal aspects are previous marriage, kinship, sex and adoption. There is little reseach about marriage capacity made in Estonia. It seems that this legal institution is taken as something self-evident - something that has always been regulated like this and there is no reason to doubt its suitability todays society.

In Estonian law according to E. Ilus (1935) marriage obstacles were absolute obstacles, which did not allow to marry at all (age, valid previous marriage, absence of the consent of the future spouses) and relative obstacles, which did not allow to marry only to certain persons (kinship). E. Ilus also classifies the marriage obstacles by the validity: „destroyable“ (kinship) and „undestroyable,“ but so called punishable (lack of the consent of the parents in case law demands it). The third classification was obstacles of public law (age, kinship - it is state's function to control it) and obstacles of private law (fraud). ${ }^{8}$

\section{Marriage}

It is understandable that marriage capacity is closely related to the definition of marriage in the different states or regions, because it depends on the connotations of marriage. In many cases there is no precise definition of marriage ${ }^{9}$ explicit in the legal acts and the section on marriage begins with the issue of

5 The „personal“ law is the law with which an individual is presumed to have most to do, and to be most in touch with - the law of his or her domicile, i.e., the la place where he or she was settled with no intention of ever permanently removing there from (Baty T. Capacity and Form of Marriage in the Conflict of Laws. The Yale Law Journal. Vol 26. No 6. 1917. P 445. http://www.jstor.org). 21.06.2012.

6 Baty T. Capacity and Form of Marriage in the Conflict of Laws. The Yale Law Journal. Vol 26. No 6. 1917. P 445. http://www.jstor.org. 21.06.2012.

7 ICCS recommendation No 2 Recommendation on the law of Marriage. Adapted by the general Assembly in Vienna 8. September 1976. http://www.ciec1.org/ListeRecommendatations.htm 20.07.2011.

8 Ilus E. Eraõigus. Konspekt.

9 For example in Finnish Marriage Law, German Civil Code, Spanish Civil Code, Estonian 
capacity (or impediments) in EU memberstates. Recently, also in the literature, the authors have been rather careful in defining the marriage as a legal institution. It seems reasonable considering that marriage as society's most vital and primary institution ${ }^{10}$ is more of a social phenomenon which has been changed enormously in the last decades.

To exemply this, there are shown different explanations about marriage: marriage can be, for example, defined as a social union or legal contract between people that creates kinship ${ }^{11}$ or a contract according to the law of nature, antecedent to civil institution, /.../ which may take place to all intents and purposes, wherever two persons to different sexes engage, by mutual contracts to live together ${ }^{12}$. Marriage is an essentially private, intimate, emotional relationship created by two people for their own personal reasons to enhance their own personal well-being. Marriage is created by the couple, for the couple. Each person has the right to express socially his or her own inner vision of family, sexuality and intimacy, on an equal bases ${ }^{13}$. Marriage is a site of various and dynamic relations, in which new conseptual tools in political and social theory might be put to work. ${ }^{14}$ Marriage is an institution deeply bound up with the system of civil society as a whole. „It is the parent and not the child of society. "15 The essencial function of marriage has always been to provide the necessary cultural framework for straight couples and their children. ${ }^{16}$ Marriage is generally considered a civil contract differing in notable respect from ordinary contracts, but it is also and specially a status or presonal relation in which the state is deeply concerned and over which the state exercises exclusive dominon. ${ }^{17}$ These are only some definitions and they differ from each other at least in some respect.

Many countries limit marriage, while some allow forms of polygamous marriage, and some recognize same-sex marriage. People marry for many reasons - legal, social, emotional, economic, spiritual, religious etc, but the causes are

Marriage Law Act etc.

10 Dobson J. C. Marriage is the foundation of the Family. Notre Dame Journal of Law, Ethics and Public Policy.2004. Westlaw. 10.06.2012.

11 History of marriage in Western Civilization.http://www2.hu-berlin.de/sexology/ATLAS $\mathrm{EN} / \mathrm{html} /$ history of marriage in western.html .

12 S. Cretney. Family Law in the twentieth century. A History. Oxford University Press. 2005. p 699.

13 Gallagher M. What is Marriage for? The Public Purpuses of Marriage Law. Lousiana Law Review. 2002. Vol 62. p 3 and 17.

14 Brook H. Stalemate: Rethinking the politics of marriage. Feminist Theory. 2002. http//fty. Sagepub.com/content/3/1/45. p 56 .

15 A. K. Kuhn. Comparative Commentaries on Private International Law or Conflict of Laws. 1937. Macmillian, p 135.

16 Yarhoyse M. A. Nowaki S., K., The Many Meanings of Marriage: Divergent Perspectives Seeking Common Ground. The Family Journal. 2007. http:tfj.sagepub.com/content/15/36. 30.04.2012.

17 Dvorske J., J., Corpus Juris Secundum. Marriage Westlaw May 2012. 
not relevant to the law because the presumption is that people marry to create families and cooperate with each other assisting the state in creating cells and partnership of good citizenry. Marriage can be recognized by the state, church or other religious authority, a tribal group, local community, organisation etc. Marriage law often reflects the moral views of certain period and/or social class. They may also be used as an instrument to faster or uphold certain social structures and developments. By binding sexuality, the creation of families, and children to marriage, an essencial part of human relations could be controlled by those who have influence over marriage rules and laws (mostly church and state). ${ }^{18}$

Marriage, as we know it in our Western civilisation today, has a long history with roots in several very different ancient cultures, of which the Roman, Hebrew and Germanic are the most important. Western marriage has further been shaped by the doctrines and policies of the medieval Christian church, the demands of the Protestant Reformation and the social impact of the Industrial Revolution. ${ }^{19}$

\section{Marriage capacity through the times in Europe}

In ancient times marriage capacity was regulated by customs. Though there were no specific ceremony, people created family in certain ages and statuses in their community. From the early Christian era (30 to $325 \mathrm{CE}$ ), marriage was thought of a primarily a private matter with no uniform religious or other ceremony being required..$^{20}$ In the era of Roman law already the impediments of marriage were assessed. As marriage was regulated by private laws, the state did not interfere on it much. Only on the 4th century the church started to give a socalled blessing to marriages ${ }^{21}$. The family law of the whole European continent before the Reformation was mainly uniform canon law. It consisted of two separate systems, catholic and orhodox, which in fact were very much alike. This unification of canon family law in the Catholic part of Europe was achieved around the 12th century, and brought about dramatic changes. In orthodox Europe, the process of unification, although more spread out in time, led to almost the same results. The developments of family law from the end of the Middle Ages until today can be seen as the gradual abandonment of concepts of canon family law. The process of gradually abandoning the concepts of canon law was essentially

18 J von Schmädel. The History of Marriage Law in Austria and Germany: From sacrament to civil contract. Hitotsubashi Journal of Law and Politics. 37 (2009) p 41).

19 J von Schmädel. The History of Marriage Law in Austria and Germany: From sacrament to civil contract. Hitotsubashi Journal of Law and Politics. 37 (2009) p 41).

20 History of marriage in Western Civilization. http://www2.hu-berlin.de/sexology/ATLAS $\mathrm{EN} / \mathrm{html} /$ history of marriage in western.html. 20.04.2012.

21 History of marriage in Western Civilization. http://www2.hu-berlin.de/sexology/ATLAS $\mathrm{EN} / \mathrm{html} /$ history of marriage in western.html . 20.04.2012. 
the same in all European countries, and took place under the influence of the same liberal ideas. ${ }^{22}$

The substance, the tendencies, and the driving forces of the reform of family law were essencially the same everywhere. The only true differences are the timing. There are no unbridgeable historical and cultural differences that make family law eternally unsuitable for harmonization and unification. ${ }^{23}$

\section{Marriage capacity in Estonia since the 13th century}

Estonian (family) law belongs to the continental legal family and has in history developed similarly to other European countries, having impacts from Roman, German, Sweden, Danish, Polish and Russian law.

In Estonia until the beginning of the 13th century, families were patriarcal, which was the prevailing form of families also in earlier times. In general, there was monogamy, though sometimes polygamy was mentioned (in case of Elders). Marriage was contracted by robbery or buying, and also voluntarily (by engagement). ${ }^{24}$ Soon after, the church took direct interest on this contract. Many marriages were still contracted by customary law. ${ }^{25}$ From the 13 th century the Estonian family law has been developed similarly to other European States and has received influences from Germany, Poland, Sweden, Danmark and Russia until the beginning of the 20th century. The church had power and played a role on these matters and the marriage capacity was controlled.

Some determining factors affecting the capacity to marry have been unchanged from Roman law or even from earlier times - age, consent of the so called legal representatives and gender. Marriage impediments were also a valid previous marriage and marriage between relatives ${ }^{26}$. There are no norms of marriage capacity in Baltic Private $\operatorname{Law}^{27}(1865)$, because marriage was fully

22 Antokolskaia M.V. The process of modernisation of family law in eastern and western Europe. Difference in Timing, Resemblance in Substance. EJCL. Vol 4.2. September 2000. Arvutivõrgus. http://www.ejcl.org/42/art42-1.html.18.05.2006. See also Antokolskaia M. V., Development of Family Law in Western and Eastern Europe: Common Origins, Common Driving Forces, common Tendencies. Journal of Family History 2003. http://jfh.sagepub.com/content/28/1/52.30.04.2012 p 53 .

23 Antokolskaia M. V., Development of Family Law in Western and Eastern Europe: Common Origins, Common Driving Forces, common Tendencies. Journal of Family History 2003. http://jfh.sagepub.com/content/28/1/52.30.04.2012 lk 53 .

24 Eesti õiguse ajalugu. Eestimaa õiguse ajalugu. Konspekt. V.E. Muhel (J. Uluotsa loengute põhjal) 1938. p 97.

25 Eesti õiguse ajalugu. p 244.

26 See also E.Ein. Perekonnaõigus. 1936. Lk 219. Arvutivõrgus: http://digar.nlib.ee/digar/ show/?id=43622. 20.04.2012.

27 The third volume of Baltic Provincial Code, which was in general the codification of local common law in force, first only for the Baltic-germans and established different rules in different areas. (Göttig T, Hallik L, Uusen-Nacke T. Abielulahutuse õiguslik regulatsioon Eestis. Juridica IV. 2006 p 245). 
regulated by the church law. Baltic Private Laws considered only the marital property regulation. After the establishment of The Estonian Republic in 1918, it was decided to reduce the authority of churches related to marriage law and recognise civil marriage. As a result, in 1922, the Marriage Law Act was passed. 2829 . According to the paragraph 4 of that law, it was not allowed for a person to marry, if permanently insane, did not understand what he/she was doing, if epileptic, in difficult forms or reproductive ills during the infection time, leper or minor under the custody of parents or guardians, without their permission, to marry. A person who wanted to get married, had to be single (no valid previous marriage). Bigamy was in fact a criminal offence.

The following relatives could not marry to each other: ascendants and decendants, uncles and nieces, aunts and nephews, stepfathers and step-daughters, stepmothers and her step-sons, brothers and sisters, half-brothers and halfsisters, adoptive parents and their adopted children as long as the adoption was valid. The age of full capacity was 20 years. Still a man of age 18 and a woman of age $16^{30}$ could marry only by the consent of their parent or guardian. The Family Law Act was adopted in $1925^{31}$, but the Marriage Law Act (1922) was applied to marriage and marriage capacity. The Baltic Private Law and Family Law Act were in force until 1941. After the occupation in 1940 the most important legal acts of Russian Soviet Republic were imposed, including the Code of Marriage, Family and Custody of Russian Soviet Republic ${ }^{32}$. By German Occupation in 1941 the rules in force before 1940 were accepted, so until 1944 the Baltic Private Law, Marriage Law Act and Estonian Family Law Act were in force. ${ }^{33}$

In 1944 the code of the Soviet Republic was re-established. According to it, the conditions to marry were age (18-years) and the confirmation that the couple have not impediments to marry with each other and that they were aware of the health conditions of the future spouse ${ }^{34}$. Marriage age could be reduced by special permission, but not more than one year. Impediments of marriage were previous valid marriage, imbecility and insanity, kinship and marriage between brothers and sisters and half-brothers and half-sisters (par 6).

28 RT 1922, 138, 88.

29 See also T. Teder. Perekonnaseisuametniku käsiraamat. Siseministeeirumi Administratiivala Kirjastus. 1939. p 273-285.

30 According to J. Uluots in the drafting process of Civil Code 1935 there was a discussion about raising or reducing the age of marriage and also about the extension of obstacles related to health. Still the obstacles to marry became the same.

31 RT 1925, 191/192, 110.

32 NSVL Ülemnõukogu Teataja 1940, nr 46 ja ENSV Teataja 16.dets 1940, nr 65, art 867, ENSV Teataja 31.dets 1940, nr 73, art 1007.

33 Göttig T, Hallik L, Uusen-Nacke T. Abielulahutuse õiguslik regulatsioon Eestis. Juridica IV. 2006. p 246.

34 Code of Marriage, Family and Custody of Russian Soviet Republic, par 4 and par 132.

(C) Palacký University Olomouc, Czech Republic, 2012. ISSN 1213-8770 (print), ISSN: 2464-6601 (online). 
The Code of Marriage, Family and Custody of Russian Soviet Republic was established in 1940, but was valid only temporarily. The grounds of marriage and family laws for the rest of republics of Soviet Union were worked out meanwhile. In 1969 a new code - The Marriage and Family Code of The Estonian Soviet Republic was passed based on the principles provided by the grounds of marriage and family laws for republics of The Soviet Union ${ }^{35}$. This Code was in force until 1995.

According to the Marriage and Family Code of Estonian Soviet Republic a person who wanted to marry, had to be 18 -years, exceptionally 17 , with the permission of an appointed administrative body (par 15). Marriage impediments were a pre-existent valid marriage, imbecility and insanity, kinship and marriage between brothers and sisters and half-brothers and half-sisters.

According to the Estonian Family Law Act of 1995, the marriage was to be contracted between man and a woman, and the marriage age capacity was 18 . Minors, from 15 to 17 could also marry with the written consent of his/her parent or guardian. In case a parent or guardian did not allow a minor to marry, permission to marry could be still given by the court. Marriage impediments were an „undissolved“ former marriage, kinship (marriage between relatives in the direct ascending and descending lines were forbidden, also between brothers and sisters and half-brothers and half-sisters, between adoptive parents and adapted children, and between the children adopted by the same person, also between persons from whom one has a guardian because of his/her limited capacity).

The Estonian Family Law Act of 2010 states that the marriage is allowed only between a man and a woman while the only impediments are being already married or not being of age. Only adults can get married. A court can extend the active legal capacity of a person who has attained at least 15 years of age pursuant to the provisions concerning the extension of active legal capacity of minors for the performance of acts required for the contraction of marriage and for the exercise of the rights and performance of the obligations related to marriage. An adult with restricted active legal capacity may marry only if he/she understands sufficiently the legal consequences of such act. If a guardian has been appointed to a person, it is presumed that the person is unable to understand the legal consequences of marriage unless otherwise provided in the ruling concerning the appointment of a guardian. ${ }^{36}$

35 NSVL ÜT 1968, 27, 241.

36 Marriage cannot be contracted between relatives in the ascending and descending lines and between brothers and sisters and half-brothers and half-sisters. These restrictions are applied also if the family relationship between the persons has terminated as a result of adoption of one person. Restriction is also applied if aforementioned family relationship is based on adoption. 


\section{Marriage capacity of EU memberstates}

In principle, in all memberstates, a person who wants to marry must be an adult (18-years old). As for minors, the age 15 or 16 (mostly 16) is the minimum age to marry but only with the consent of his/her legal representative or the court. Only in Spain can already 14-year old minor marry (with the permission of court or other institution).

An obstacle that only persons of different sex can marry has made most enormous change in resent years. There are some states, where same-sex marriages are still forbidden ${ }^{37}$, but in some countries they are allowed ${ }^{38}$ or their relation is regulated by registered partnership laws ${ }^{39}$. Usually being in an registered partnership is also an impediment to marry, except the marriage between those who are in registered partnership with each other. Allowing same-sex marriages has had different debates in EU memberstates, but in the end many states have regulated it. A similar pattern of development can be notices to the reform of family law separating from canonic family law.

A similar treatment is given to the principle of monogamy. No marriage can be contracted if one of the spouses is already enagaged in a valid marriage.

Impediments related to kinship are also regulated harmoniously. The general rule is that blood relations in straight lineage and siblings of both full and half-blood cannot marry. Still there are exceptions related to those restrictions and the marriages are allowed with the permission of court (Germany, Spain, France, Slovenia, Poland), Minister of Justice (Finland, Netherlands, Sweden) or the king (Belgium). The marriage between adopted child and adoptive parent is not allowed in Europe, with the exception of Switzerland.

It is interesting to notice that in Italy, Spain and Portugal is marriage prohibited if the marriage is entered into by two people, one of whom has been convicted of the murder or attempted murder of the other's spouse ${ }^{40}$. In Spain, the pardon for this restriction can be granted by the Ministry of Justice.

Another remarkable impediment is the one related to the health of spouses. In some states there is needed even a medical certificate (Bulgaria, Rumenia, Luxemburg), in others impotence is an impediment to marry (Malta, Ireland, Scotland).

37 For example in Estonia, Greece, Ireland, Italy, Latvia, Lithuania, Malta, Poland, Slovakia etc.

38 The first state to allow same-sex marriage was Holland in 2001. Holland was followed by Belgium in 2003, then Spain in 2005, Sweden in 2009 etc.

39 For example in Croatia, Danemark, Finland, France, Germany, Hungary, Island, Great Brittain etc.

40 Von Freyhold, Vial \& Partner Consultations, (2008) Facilitating Life Events, Final Report for the European Commission, DB-Directorate-General for Justice, Freedom and Security on the project No JLS/2006/C4/004 http://ec.europa.eu/civiljustice/publications/docs/ study_ms_legislation_country_reports_en.pdf. 12.05.2012. 
In the United Kingdom if at the time of marriage a woman is pregnant by some other that the other contrayent then an impediment arises. ${ }^{41}$

Notable is also an impediment in Austria, by which in case one of the spouses was mistaken about the identity of the other spouse, the marriage is not valid. ${ }^{42}$

\section{Values in society and marriage capacity}

Legal norms express the values in society. It should be inevitable to relate laws to the society, but how much legal norms actually reflect values? Values are not original but derivative.$^{43}$ Therefore law is in a continuous development what was accepted yesterday, can not be acceptable, contemporary and relevant to the principles suitable in today's society, not speaking about tomorrow. It often happens in practice that rules established with one aim, are applied instead with other purposes. But also contemporary cultures are not a static mediums they are in fact, influenced by change and efforts to develop at many levels ${ }^{44}$.

The cultural history of the twentieth century can be understood as a gradual acceptance of „social rights“ ${ }^{\text {“5 }}$. Such progress towards total tolerance is interpreted as the possibility to live „as one wishes ${ }^{46}$. Although people might not really want total freedom, they need regulations that protect morals and traditions. And yet, morality and traditions are changing as well, and too fast. Lõhmus (2003) explains that high degree of generalisation in Estonian constitution (par 12) and in the convention of Human Rights (art 14) allows attend to the changes and developments and adapt to different needs and level of developments of state and society ${ }^{47}$.

Marriage capacity is directly related to the social values. As refered earlier, these social values are different in every memberstate. A comparative analysis shows that the marriage capacity regulation is not so dissimilar in Europe.

41 Von Freyhold, Vial \& Partner Consultations, (2008) Facilitating Life Events, Final Report for the European Commission, DB-Directorate-General for Justice, Freedom and Security on the project No JLS/2006/C4/004 http://ec.europa.eu/civiljustice/publications/docs/ study_ms_legislation_country_reports_en.pdf .12.05.2012.

42 Von Freyhold, Vial \& Partner Consultations, (2008) Facilitating Life Events, Final Report for the European Commission, DB-Directorate-General for Justice, Freedom and Security on the project No JLS/2006/C4/004 http://ec.europa.eu/civiljustice/publications/docs/ study_ms_legislation_country_reports_en.pdf.12.05.2012.

43 Raska E. Olemise õigus.TTÜ õiguse instituut.Sisekaitseakadeemia. Sisekaitseakadeemia.2010 p 65.

44 Michelle Le Baron, Transforming Cultural Conflict in an Age of Complexity, http://www. berghof-handbook.net/documents/publications/lebaron_hb.pdf.26.05.2012 . Lk7.

45 R.R. Reno „Marriage, Morality, and Culture“. 2009. http://www.firstthings.com/onthensquare/2009/09/marriage-morality-and-culture 26.05.2012.

46 R.R. Reno „Marriage, Morality, and Culture“. 2009. http://www.firstthings.com/onthensquare/2009/09/marriage-morality-and-culture 26.05.2012.)

47 Lõhmus K. Võrdsusõiguse kontroll Riigikohtus ja Euroopa Inimõiguste Kohtus. Juridica.2003. II. P 107. 
Although there are some variations - for example, the age of minors to marry, differs only in some years, some states allow marriage between close in kin, with special permission, etc. Social values are the same related to monogam $y^{48}$ and in general related to kinship. The issue of gender is being discussed mostly in resent years and a very strong movement towards harmonisation is taking place on this regard. Twenty two of the Council of Europe's forthy-seven memberstates legally recognize same-sex relationship in some way ${ }^{49}$. States like Estonia who strongly declare that same-sex marriage is not compatible with their tradition, should think about their attitude towards cohabitation years ago - it was not considered morally adequate then. In contrast, today a person who is married, is the exeption, considered oldfashioned and weird. Nowadays no clear statements holds better than others the values of our society - is it any more acceptable a marriage or cohabitation? Too often also scientists and politics are puzzled to define marriage arguing that marriage is the only social value a state has to protect ${ }^{50}$. George and Elehtain have said that given the importance of marriage as an institution for individuals and for society, the thoughtful citizen has every reason to expect, and even to demand, a deep and thoughtful debate as the precondition for any change in how we understand marriage and encourage it to take shape. ${ }^{51}$

No research on marriage in Estonia has been made in recent years. In earlier studies it appears that there is no consensus about the definition or content of marriage. While some authors have found that in Estonia cohabitation ${ }^{52}$ is an alternative form for marriage (Kasearu 2004, Tiit 2003, Titma ja Saar 1997), (Järviste, Kasearu, Reinomägi 2008), (Kama P, Kullerkupp K), ${ }^{53}$ others consider only marriage the ideal precondition for a family to be configured ${ }^{54}$.

Family patterns are changed because of the cultural changes in society. One of the important factors here is the growth of individualism, where individual becomes in his/her choices and preferences more confident and follows personal

48 Though there are also reflected protests againts it by the social groups with different religious tradition.

49 Cooper S. L., Marriage, Family, Discrimination \& Contradictions: An Evaluation of the Legacy and Future of the european Court of Human Rights' Jurisprudence on LGBT Rights. German Law Journal. 2011. Vol 2. No 10. P 1747.

50 According to Estonian Constitution marriage is under the protection of state (par 27)

51 George R.P., Elehtain J.B. The Meaning of Marriage. Family, state, market and morals. http://www.amazon.com/The-Meaning-Marriage_Family-Market/dp/189062664\#reader_ B0047DX11G.24.06.2012.

52 Cohabitants can be defined as a couple not married, having children and living as a one household plenipotentiary (Kasearu K., Cohabitation in Estonia and Europe - do Estonians prefer cohabitation due to the financial reasons? Sotsiaalministeeriumi toimetised. 3/2008. p 31).

53 In 2002 they declared that „It is popular to say, that cohabitation isi n its sociological comparison equal with the family." (Kama P., Kullerkupp K., Vabaabielu versus abielu: varalised suhted muutuvate kooseluvormide kontekstis. Juridica. 2002. VI. P 359).

54 Kasearu K., Cohabitation in Estonia and Europe - do Estonians prefer cohabitation due to the financial reasons? Sotsiaalministeeriumi toimetised. 3/2008. p 31. 
interests (Beck and Beck-Gernsheim 2002). Also secularisation is relevant by which essential moral norms based on Christian worldviews have decreased. New family laws that are predicted on the fundamental principle of gender equality and are informed by the provisions of the international conventions relating to family life, have enacted. Tsaoussyhas sayd that these legislative changes have gone hand-in-hand with the growing complexity of family life, which in turn is closely interrelated with larger social trends, such as individualization and secularization. ${ }^{55}$

According to the European Social Survey in $2007^{56}$ marriage is highly valued in Estonia (85\% of respondents support the tradition of marriage), $72 \%$ claimed that marriage is not obsolete. By the everyday practice one could claim that after five years from this study, the society values related to marriage have been changed, as well as the general support towards marriage, that statistics show is not so high any more.

K. Kasearu (2006) argues that in comparison to other states, cohabitation in Estonia has become an alternative to marriage, but this does not mean that intentionally has been decided to abandon marriage or that people have clear negative attitude to marriage. When she asked, whether marriage as an institution has weakened and cohabitation and marriage have become similar, The answer is yes and no. As the differences between cohabitation and marriage are blury, also the boundaries of marriage and cohabitation are. In the last decade of past century and at the beginning of this century, an obvious trend emerges in recognition and legalization of cohabitation in Europe (Bradley 2001) $)^{57}$. In Estonia, the state does not say directly that marriage is oldfashioned or that marriage and cohabitation have the same legal meaning. Still in many areas it has recognized to those who live in cohabitation the same rights as those who are married. Some legal acts state next to the word "marriage“ also „cohabitation“.58 The court practice has recognized in cases also cohabitation rights similar to rights derived from marriage.

Considering these developments, it is important to think about the value of marriage. Marriage capacity is partly related to biological and cultural reasons. Prohibition to marry between close relatives derives from ethical and biological considerations. According to ethical considerations marriage is prohibited also between adoptive parents and adopted children. Substitute parents and their relatives become legally relatives of an adopted child, so it would be inconsistent to the objective of adoption and moral norms not to have the same prohibition.

55 Tsaoussi A. The Economics of Family Law. Working Paper Series. April 2007. SSRN:http:// ssm.com/abstract $=1116386$.

56 www.europeansocialsurvey.org

57 Järviste L., Kasearu K., Reinomägi A. Abielu ja vaba kooselu:trendid, regulatsioonid, hoiakud. Poliitikaanalüüs. Sotsiaalministeeriumi toimetised nr 4/2008. lk 2.

58 For example Public Service Act, Procurement Act, Civil Procedure Act, Criminal Procedure Act, Imprisonment Act etc). 
With the same logic, this extends to marriages between step-father and stepmother, step-daughter and step-son. The biological argument seeks to protect person descendants from inheritable malformation. ${ }^{59}$

Meanwhile, people who want to marry are imposed these restrictions, but people living in cohabitation are not. The state does not interfere or has any possibility to refer to the possible inheritable malformation that descendants might suffer. When the society values change so rapidly, then the norms providing kinship as an obstacle to marry do not fulfill their objective. This situation creates inequalities. On the other hand, admittedly in history this prohibition has not been so rigidly applied ${ }^{60}$ and as already mentioned also today in some EU memberstates it is allowed to marry a person next in kin. The state should analyse the questions related to marriage and cohabitation in coherence. If the state gives to cohabitation an equal position compared to marriage then also the impediments to marriage should be simplified.

K. A. Collins (2009) explains that already in the 19th century in America there was the question to clarify the distinction between marriage and nonmarriage, strenghtening the government's role in the regulation of marriage, especially with respect to regulating who could marry who. ${ }^{61}$ As suggested before, it seems that the values related to marriage and marriage capacity are not considerably different in EU memberstates. In this sense we can talk about one common value space related to marriage capacity. Differences of traditions and cultures do not play here a considerable role. Society changes, and some states are just faster to adapt their law to those changes. The others should learn from them because what they call a tradition is not a tradition any more and immorality is understood as a normal figure.

M. Gallagher (2002) said that making substantial progress in reversing the trend towards family fragmentation will require that law and society reject the deepest presumptions driving postmodern family as an ideological and legal construct: the idea that marriage is essentially a private choise created by and for the couple; that children do just fine in whatever family forms their parents choose to create; that babies are irrelevant to the public purpuses of marriage. ${ }^{62}$

According to Browning and Marquardt (2010) the growth of technical rationality - „efficient means-ends procedures, coming from either market or state bureaucracy, that accomplish short-term satisfaction" - thoroughout society has increasingly uprooted traditional family roles. ${ }^{63}$

59 Turkin V. Perekonnaseaduse kommentaarid ja selgitused. 2007. lk 14.

60 Cretney S. Family law in the twentieth century. A History.2006. lk 52.

61 Collins K.A. Administrating Marriage:Marriage-Based Esntitlements, Bureaucracy and the Legal Construction of the Family. Vanderbilt Law Review. Vol 62. Nr 4. 2009. 1k 1121.

62 Gallagher M. What is Marriage for? The Public Purpuses of Marriage Law. Lousiana Law Review. 2002. Vol 62. p 18.

63 George R.P, Elshtain J.B. The Meaning of Marriage. Family, state, market and morals.Scep- 


\section{Values and law-making process}

Law is an important and convienient agent of socialization, which explains by it's preceptions to the members of society social, cultural, political etc values and refers what is the accepted behaviour and what is not. ${ }^{64}$

Values act an important role also in the process of law-making. The objective of legislature must be to recognize what is considered important by the population, so laws are not to establish lawsthat only the creator of the law considers appropriate but first of all what society believes correct, that is a good and functioning regulation, which is created by a legislative process with the support from the society. For the interests of legal order it is inevitable to recognize the pluralism on values and those values must be considered and balanced. Though there can be conflict between the different values, it cannot be said that those values are in conflict with each other - they can be competitive and conflict could be solved taken into consideration their relative values and importance. ${ }^{65}$

I. Teder (2012) has said, that in law-making processes the legislator must consider that the whole law is a regime of values - every interest is corresponding to certain value. Clearly, as I. Teder mentions, positivism shapes those values. ${ }^{66}$ And here is where the formality of legal norms plays role - the clearer the norm, the better to identify the meaning of it. Scientifically correct and objective-oriented law-making is not possible without the help of social scientists. Comprehensive scientific research must precede law-making. It is impossible to create law in an empty place and without considering the understanding of the values in society. Just like Evan (1990) states, with few exceptions, law-makers do not understand that the laws they make need systematic empirical study and assessment $^{67}$.

Also Estonian law must follow the social source and essence of law. As a memberstate of EU Estonia must consider in creating, organising and dispos-

ter Publishers. 2010.

64 Armand M. Õigus ja selle legitiimsus õiguspoliitika teostamise eeldusena. Vaateid õiguspoliitikale. Artiklite kogumik Koostanud ja toimetanud S. Kaugia. 2008. Lk 49. Viidatakse Silvia Kaugia. Õiguse sotsioloogia: Õigus kui sotsiaalse kontrolli instrument. Sissejuhatus õigusteadusesse. Loengud. Tallinn.2003.p 45.

65 Armand M. Õigus ja selle legitiimsus õiguspoliitika teostamise eeldusena. Vaateid õiguspoliitikale. Artiklite kogumik Koostanud ja toimetanud S. Kaugia. 2008. Lk47. Viidatakse M.L.F. Esteban. The Rule of Law in the European Constitution. Hague. Kluwer Law International. 1999. p 40.

66 Teder I. Ettekanne „Raha ja põhiõigused“ Eesti-Saksa sümpoosiumil. Arvutivõrgus: http:// oiguskantsler.ee/et/oiguskantsler/suhted-avalikkusega/koned/indrek-tederi-ettekanneraha-ja.pohioigused-eesti-saksa 27.01.2012.

67 Armand M. Õigus ja selle legitiimsus õiguspoliitika teostamise eeldusena. Vaateid õiguspoliitikale. Artiklite kogumik Koostanud ja toimetanud S. Kaugia. 2008. p 58. Viidatakse edasi W.M Evan. Social Structure and Law. Theoretical and Emprical Perspectives. London. 1990. p 232-234. 
ing its internal law the trends of EU socio-philosophical, ethical and regulative trends in this area of law. ${ }^{68}$

Every draft of law must precede an assessment of impacts. Assessment of impacts is a process, by which evidence of advantages and disadvantages of policy options and their potential consequences are collected for the policymakers. ${ }^{69}$ Evaluation of already passed legal act is not less important. In an explanation letter of draft of law there must be a plan for evaluation. ${ }^{70}$

According to good standard techniques, in every draft of law, also social impacts must be assessed ${ }^{71}$ and reasoning on the draft must consist an explanation of the analyzes of such impacts (par 46 sec 1 subs 1). Assessing the social impacts is complicated, time-and resource consuming process, but without it law cannot be made or changed - every decision made by the certain reason influences social process in some extent. ${ }^{72}$ New policy of working out the new draft of law provides scientific research as an obligatory part of $\mathrm{it}^{73}$, but today in Estonia there is no explanation how to fulfill this obligation: where is the list with researchers ministries could hire to assess social impacts.

The draft of a legal act is compiled to regulate social relations if the necessary regulation is missing or the previous regulations are outdated or insufficient ${ }^{74}$. Draft of the law must be compliant to the constitution, general principles and norms of international law, treaties and EU law (par 3).

Assessment of impacts is oriented also to the legitimacy of legal regulation. An explanation letter of the legal acts gives a possibility to understand the objective and meaning of the legal norm and gives confidence to the implementer that he/she makes a decision, which is relevant to the requirements ensuring the legitimacy of the decision.

Today the Estonian laws can be described as chaotic - too many legal norms are in contradiction and there is little understanding in relation to EU principles. It all has made uncertainty in applying the norms. And there is also an eclectic practice in administrative field. The prevailing view is that every decision can easily be sued in court. If to ask from the authorities who have worked out the drafts, what is the meaning of the norm, then the suggestion is to interpret the

68 Armand M. Õigus ja selle legitiimsus õiguspoliitika teostamise eeldusena. Vaateid õiguspoliitikale. Artiklite kogumik Koostanud ja toimetanud S. Kaugia. 2008. p 60.

69 Mõjude hindamise metoodika. 2012. Eelnõu. Lk 3. Vt ka Euroopa Komisjoni mõjude hindamise juhend (2009) did Estonia need this juhend to realise it was fundamental? http:// ec.europa.eu/governance/impact/commission guidelines/docs(iag 2009 en.pdf).

70 Mõjude hindamise metoodika. Justiitsministeerium ja Riigikantselei. 2012. Eelnõu.

71 RT I , 29.12.2011, 228.

72 A.Saar. Miks on vajalik sotsioloogiline ekspertiis. Lk 1. Arvutivõrgus: https://www.ut.ee/ haridustehnoloogia/projekt/kursus2/5_miks_on_vajalik....3.05.2012.

73 Mõjude hindamise metoodika. Justiitsministeerium ja Riigikantselei. 2012. Eelnõu.

74 Hea õigusloome ja normitehnika eeskiri par $2 \sec 1$.

\section{(C) Palacký University Olomouc, Czech Republic, 2012. ISSN 1213-8770 (print), ISSN: 2464-6601 (online).}


legal norm by yourself or wait for the court practice. Such insecurity does not uphold the principle of the rule of law and certainly not a legitimate legal system. This uncertainty could be avoided if legal norms would get their meaning already in the process of establishing them. But this needs correct social analysis, which usually has not been done. It is a major concern that the developed practice in Estonia where on the one hand the state establishes principles to ensure that lawmaking relies on scientific research, but in reality the practice evades these rules. If the process of law-making is directed only to solve individual cases and in the process of resolving it the whole legal act, branch of law, Estonian law principles or EU law has been ignored, this will lead to the situation, where legal acts are in permanent change splitting the stability of Estonian law and legal certainty for a citizen. Assessment of impacts is important and helps in a large extent to clarify the content of the norm.

Mature societies learn from the mistakes of others and can take over suitable ideas to solve problems. In todays EU law space it is also evident, because memberstates influence each other anyway, science-based political decisions cannot be made without comparative analyze of other EU memberstates. This obligation in law-making process is related to the asessment of impacts, because not only the legal norm as a set of words or sentenses does not give the meaning of the rule ${ }^{75}$.

Socio-cultural (the changes of general values and understandings of society) and socio-psychological (changes the values and understandings of an individual) impacts are influencing also each other and this makes the values in continious changes and therefore difficult to follow. ${ }^{76}$ Who should perform social impacts - social scientists or lawyers who implement the law? If in the legislative process an assessment of impacts has not been made, then a lawyer implementing a law, must study those values which should have been outlined already in the legislative process and should be found by the implementer from the explanation letter of the draft of law.

As mentioned earlier the law-making process plays an essencial role in confirming the values. It is even obligatory to make research of social impacts. Also, state should make such reasearches continuosly. It is important especially related to family law because society is changing all the time and recent decades has family law in social sense (not in the regulations) changed in substantial amount.

For the purposes of this article, the documents prepared in the legislative process of Estonian Marriage Law Act 2010 were assessed, to try finding out the social values that these norms regulate. In an explanation letter of Estonian new Family Law Act (in force from 01.07.2010) the following can be found: „The draft

75 It is important to find an objective of the rule. If we do not know even an objective of our legal norms, then maybe other states have the same problem?

76 Järviste L, Kasearu K, Reinomägi A. Abielu ja vaba kooselu: trendid, regulatsioonid, hoiakud. Poliitikaanalüüs. Sotsiaalministeeriumi toimetised nr 4/2008. p 2. 
does not make any changes in the prequisites for marriage compared to the former act. As usual there is a principle that marriage is contracted between a man and a woman for an unlimited time. Prerequisite for marriage is still majority of spouses (18-years of age, deriving from the Code of Civil Code Act). The only remarkable difference from the previous regulation is that 15 -year old minor can marry with the consent of court77."

Here is important to refer that the drafting process of Family Law Act was started already in 2006. In 2009 a study of cohabitation and its legal regulation was made $^{78}$. In this, a general overview about same-sex marriage and partnership was included, also referended to decisions and opinions of European Court of Human Rights and different interpretations of EU law and international conventions. As the only research related to cohabitation was made in Estonia by Järviste, Kasearu and Reinomägi ${ }^{79}$ in 2008, this was the main document together with Population Census from 2000 the Estonian values were based on.

This study refered to the traditional definition of marriage, which consists of the purpose of having children, but on the other hand refer to the fact, that that protection of the traditional family and having children is not so important anymore, according to legal scholars. In this work, research related to marriage capacity was not made, and also it did not answer clearly to the question „What are the values of marriage in Estonia, the norms in Estonian Family Law Act protects?". However, they concluded, that according to Estonian and German constitutional law and in international legal acts marriage is addressed as a union between a man and a woman. The Court of Human Rights and European Court does not consider mandatory for memberstates to give the right to marry to the same-sex couples ( $\mathrm{p} \mathrm{85})^{80}$. This article claims that that these conclusions were made based on the legal norms regulating marriage capacity, but absent the assessment of social impact.

When the draft reached to the Parlament an evaluation of social impacts for the Marriage Law Act was ordered from a research group leaded by the Institute of Sociology and Social Policy of Tartu University. According to its introduction the objective of it was that the new Family Law Act would correspond more to the human behavior and social developments in Estonia.

"Every change in law causes changes also in attitudes, systems of values and human behavior, leading to new social developments. It is not obvious how will new laws affect Estonian society and correspond to the objectives of interna-

77 Earlier only the consent of the parents of the minor were needed.

$78 \mathrm{Olm}$ A. Mitteabieluline kooselu ja selle õiguslik regulatsioon. 2009. http://www.just. ee/35424.

79 Järviste L, Kasearu K, Reinomägi A. Abielu ja vaba kooselu: trendid, regulatsioonid, hoiakud. Poliitikaanalüüs. Sotsiaalministeeriumi toimetised nr 4/2008. p 2.

$80 \mathrm{Olm}$ A. Mitteabieluline kooselu ja selle õiguslik regulatsioon.2009. http://www.just. ee/35424. 
tional and state development. New law is related to the whole citizenship, which gives to legislator a high responsibility, and is accompanied by the need to analyse properly all possible consequences derived from the new law. The objective of this analyse is to study most important direct and indirect social impacts in the level of individual, family and society. The study emphasizes the differences between norms and systems of values, growing individualisation in society in general, principle of social ethics: equal rights and possibilities to everyone related to the trend turn more attention to the individual, not to the group. This individualism can jeopardise the institute of marriage as the support of current societies. In the text the developments of values of this law are also studied in the light of - negative freedom (the richer the person the more freedom he/she has) or positive freedom (cohesion, relations, responsibility) ${ }^{\text {(81. }}$.

Unfortunately this analyse addresses only marriage property and relations between parents and children. The only reference related to marriage capacity is that individualisation of property challenges the marriage institution. Problematic will be the meaning of marriage and its discrepancy to the reality. The Act emphasizes the individual responsibility, but here also the conclusion was based only on the marriage property selected by the marriage. Expand, this is relevant. Also this analyse did not address marriage capacity, though one should predict that by the introduction.

In the process of adopting the new Family Law Act, Erik Salumäe, a member of Parlament said: „We have to consider, that Family Law Act is absolutely related to every person and in such cases legislator cannot make rash decisions ${ }^{82}$. It is evident that the act is not a panacea, which makes people better to each other or ensures happy life for every family, but the legislator can establish a contemporary legal environment, which creates conditions in which more people want to get married and where the rights of every single member of the family are protected. ${ }^{83}$

From the documents explaining the social impacts of the new family law act no assessment of the marriage capacity related to the values in Estonia is found.The only development related to the marriage capacity is the change that instead of parents or guardian (legal representatives) the permission to marry for a minor is given by the court. In an explanation letter the demand for the change is explained by the fact, that court can better assess the mental readiness to contract the marriage. An essential social analys, by which such decision was made, is missing.

81 Perekonnaseaduse eelnõu sotsiaalsete mõjude analüüsi aruanne. Tartu 2008. p 2-6.

82 XI Riigikogu stenogramm, V istungjärk. 21.05.2009. http://www.riigikogu.ee/?op=steno \&stcommand=stenogramm\&pkpaupa $=1 \&$ toimetatud $=1 \&$ toimetamata $=0 \&$ date $=124289$ 3713\&paevakord $=4415.04 .06 .2012$.

83 XI Riigikogu stenogramm V istungjärk. 21.05.2009. http://www.riigikogu.ee/?op=steno\&s tcommand=stenogramm\&pkpkaupa $=1$ \& toimetatud $=1 \&$ toimetamata $=0 \&$ date $=12428937$ 13\&paevakord=4415 .04 .06 .2012 . 


\section{Conclusion}

Marriage Capacity is a legal requirement closely related to the values of society. On the one hand it consists of single elements, which have been existing from the Roman times and even earlier and have changed by the developments of societies. In Europe, marriage capacity has gone through a rather homogenious developments. Globalisation and individualism have greatly influenced the marriage in general and marriage capacity in particular. According to Romualdo and Eclavea (2012) the public policy must favour the institution of marriage as a social institution to foster and protect it, encourage parties to live together and prevent separation. ${ }^{84}$ An important characteristic of marriage to promote procreation has been fading and new values are emerging vigorously. Still there is some kind of hesitation to define marriage and its content and values. Many EU memberstates have legalised same-sex marriages or partnerships, free movement of EU citizens force also those states who have still been against samesex marriages, to find solutions for cross-border family cases, where the family members are same-sex couples. In such a problematic context, Estonia has refered to the traditions of marriage, but analizing the law-making process of Estonian Family Law Act 2006-2010 there is no evidence to a tradition that could be excluding same-sex marriages. Even more - in this process marriage capacity was'nt studied at all in respect of social values.

Family law is a sphere, where research must be done constantly. Related to marriage capacity and considering the fast changes in society, all impediments by the values they carry should be analyzed to assess their correspondence to contemporary society.

84 Romualdo P, Eclavea J.D. Marriage. American Jurisprudence, Second Edition, p 1. Westlaw, 12012. 